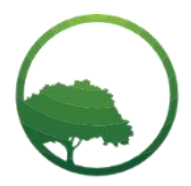

Research in Business \& Social Science

IJRBS VOL 10 NO 3 ISSN: 2147-4478

Business \& Social Science IJRBS

\title{
Examining the competitiveness of banking sector in Sri Lanka
}

(D) Champika Liyanagamage

Senior Lecturer, Faculty of Management Studies, The Open University of Sri Lanka, Nawala, Nugegoda, Sri Lanka

\author{
ARTICLE INFO \\ Article history: \\ Received 06 March 2021 \\ Received in rev. form 10 April 2021 \\ Accepted 14 April 2021 \\ Keywords: \\ Bank Competition, Panzar-Rosse \\ Approach, Banking Sector, State- \\ Owned Banks, Sri Lanka \\ JEL Classification: \\ C51, G21, G28, E32
}

\begin{abstract}
A B S T R A C T
The banking sector in Sri Lanka has been portrayed by significant changes in the past few decades. It is widely perceived that competition in the Sri Lankan banking sector has improved since the introduction of the financial sector reforms in the 1990s. By applying Panzar-Rosse (PR) approach to test the degree of competitiveness, this paper assesses the validity of this claim in the context of the Sri Lankan banking sector during 1996-2018. The sample covers a broader set of bank-level panel data of the whole commercial banking sector which comprised of 25 licensed commercial banks. The EGLS procedure applied in this study revealed that during the stated period, the Sri Lankan banking sector had been moderately competitive. Further analysis also disclosed that there is no significant difference between the state-owned banks and private banks regarding their degree of competitiveness, as well as their temporal dynamics. Another striking observation revealed in this analysis is the lower level of competitiveness among foreign banks compared to the competitiveness of local banks. The Competitiveness of the Sri Lankan banking sector however is characterized by non-price competition, as on many occasions the interest rate depends on government policies. Hence, this study provides new insight into the nature of financial sector competitiveness in underdeveloped countries. The outcome of the research implies the necessity of attempts of all banks towards re-aligning their strategies to attract and retain customers. This would be the major challenge that banks face in accomplishing $a$ higher level of competition in the banking industry in the future.
\end{abstract}

(C) 2021 by the authors. Licensee SSBFNET, Istanbul, Turkey. This article is an open access article distributed under the terms and conditions of the Creative Commons Attribution (CC BY) license (http://creativecommons.org/licenses/by/4.0/).

\section{Introduction}

Competition is a process of contention among firms seeking to secure customers' business over time. According to the economic theory, competition is needed for enhancing social welfare and efficiency. As in other sectors, the intensity of competition in the banking sector is vital for determining the efficiency of financial services, the quality, and the level of innovation of such services in the financial sector. Consequently, bank competition is a major indicator of the financial sector development of a country.

Traditional Industrial Organization models predict that restricting competitive efforts will explicitly create welfare losses (Klein, (1971). The common wisdom until 1970's was that financial repression is an essential precondition to boost investment and growth of an economy. In a repressed financial system interest rates and volume of finances are deliberately controlled.

Lateral economic theories presented by McKinnon (1973) and Shaw (1973) identified competitiveness in the financial market as an important condition necessary for economic growth and suggested financial liberalization in developing countries. Their analysis further reveals that allowing market forces to determine real interest rate will exert positive implications on the rate at which an economy can grow. Consequently, many developing countries in South America, Africa and Asia that were deemed to be repressed economies in terms of financial policies, embraced financial liberalization measures. Sri Lanka has not been an exception. A series of financial sector reforms, along with the economic liberalization policies were introduced in 1977 and they paved the path to competitiveness in the Sri Lankan banking sector.

Over the past few decades many economic forces, including technological inventions and prudent monetary and fiscal policy, contributed unprecedented growth experienced by developing economies (Guzman, 2000). Banking sector of Sri Lankan is also

* Corresponding author. ORCID ID: 0000-0002-1147-168X

(C) 2021 by the authors. Hosting by SSBFNET. Peer review under responsibility of Center for Strategic Studies in Business and Finance. https://doi.org/10.20525/ijrbs.v10i3.1095 
symbolized with various significant changes throughout last three to four decades. Technological development, entry of new dynamic banks, introduction of new financial products and services, financial liberalization together with continuing regulatory integration have contributed towards the efficiency in the Sri Lankan banking sector. Nevertheless, the banks in underdeveloped economies are functioning in a climate where the regulatory framework or the pre-conditions for such competition is deficient (Fry, 1995). Consequently, the collective net effect of aforementioned economic forces on the intensity of competition in such economies is ambiguous and less uncovered.

Sri Lankan banking sector comprised with licensed commercial banks and licensed specialized banks. Sri Lankan financial sector is bank based where the licensed commercial banking sector dominates the financial system. It represents more than $50 \%$ of the entire financial system assets of the country. Therefore, the stability and competitiveness of the whole financial system heavily depend on the performance of the commercial banking sector. The banking sector of Sri Lanka reflected with major developments with broad range of reforms introduced since early 1990s. These reforms targeted most of the institutional elements of a modern financial system. Advances in technology, new types of forceful bank firms, innovative financial products and services, financial liberalization, and the ongoing economic and regulatory integration have increased the degree of competition and efficiency in the Sri Lankan banking sector. These have further affected the changes in the market structure of the banking sector. It is generally felt that competitiveness in the Sri Lankan banking sector has improved from the time when financial sector reforms introduced in 1990's. Therefore, the main objective of this study is to examine the level of competitiveness in the Sri Lankan banking sector. Using panel data of commercial banks for the time frame 1996-2018 and utilizing Pazar-Rosse revenue equation, the present paper evaluates the validity of this assertion in the Sri Lankan context. The findings will provide a new insight into the nature of competitive environment in developing countries and will help in vital policy formulation in such economies. The contribution of this paper is twofold; first, this study is one among the few banking studies to test the degree of bank competitiveness covering a larger sample period. Second, it uncovers rather scares and robust evidence on the differences of competitive conditions among ownership forms of Sri Lankan banks, which fill up an empirical gap in the Sri Lankan banking literature.

\section{Literature review}

\section{Theoretical Background}

There are basically two approaches of measuring competitiveness in an industry namely structural and non-structural approach. Structural approaches as its name suggests measure the degree of competitiveness based on the number of firms in the market and hence through the market power of the individual firm. However, recent theoretical literature started to question about measuring bank competitiveness by using structural approaches. New Empirical Industrial Organization (NEIO) literature analyzes firms` conduct directly, instead of relying on observations on the market structure. These are called non-structural approaches to measure competition. The Lerner index is a well-known traditional measure of bank competition through which bank competition is directly measured from the markup on cost prices. This has been extensively used in the context of the so-called NEIO perspective where researchers have estimated the parameters of a firm's behavioral equation to directly obtain measures of marginal cost.

Maudos and Guevara (2004), in their study on factors explaining the interest margin in the banking sector in the European Union (EU), market power was proxied by the Lerner index. The results revealed that the drop of interest margins in the European banking system is consistent with the growth of market power. Again in 2007, Maudos and Guevara estimate Lerner indices of market power for different banking products, namely loans and deposits, in the EU banking sectors. They analyze the relationship between market power -Lerner index- in the loan and deposit markets and efficiency in the EU15 countries over 1993-2002 and confirm the positive association between market power and cost $\mathrm{X}$ efficiency. Their results further show that the welfare gains associated with a reduction of market power (Lerner index) are greater than the loss of bank cost efficiency. Lerner index has also been used in Hainz et al (2013) to measure the degree of bank competition. They develop an empirical cross-country analysis based on the regression of the presence of collateral on bank competition measured by the Lerner index. Their empirical tests corroborate the theoretical predictions of a negative role of bank competition on the presence of collateral.

However, the lack of detailed information on costs and prices of bank products makes the use of Lerner Index an extremely difficult task in practice. Therefore, the literature proposes various indirect measurements to assess the level of competition in the banking sector. Bresnahan (1982) and Lau (1982) introduce a short-run model for estimation of the market power of a bank. The model uses the condition of general market equilibrium. The basic idea is that profit-maximizing firms in equilibrium will choose prices and quantities so that marginal costs equal their (perceived) marginal revenue. Empirical research of the Bresnahan model is relatively limited. It has been estimated by Shaffer (1989) to several decades of US loan markets banking data. The results robustly deny monopoly and are consistent with perfect competition. Also, Shaffer (1993) used Bresnahan model for the Canadian banking industry and found that industry has resembled perfect competition over the last twenty-five years.

The alternative approach is Panzar and Rosse approach (PR, 1987). Panzar and Rosse (1987) develop a model which is based on empirical observation of the impact on firm-level revenues of variations in factor input prices. This measure is grounded in the idea that competitive firms are price takers and must pass through any cost changes to customers to maximize profit, whilst a monopoly firm is able to change the quantity of output to face higher input prices. Recently, a new approach to measuring competition has been 
introduced by Boone $(2000,2004)$. The main idea underlying this indicator is that in a competitive market, efficient firms can gain market shares.

\section{Empirical Background and the Conceptualization}

The Panzar Ross model has been extensively used in most empirical studies. The PR H-statistic is the sum of the elasticities of a firm's total revenue with respect to its factor input prices. Shaffer (1989) to the first time applied the Rosse-Panzar test to New York banking industry. He has shown that the $\mathrm{H}=1$ for both natural monopolists, and for sales maximizing firms which expose to breakeven constraints. Similarly, PR approach has also been used by Nathan and Neave (1989), for the Canadian financial system. Their elasticity measure was positive and significantly indicating that Canada's financial system does not show signs of monopoly. For European banking data by Molyneux et al. (1994) utilize the Rosse-Panzar statistic to assess competitive conditions in major European countries banking markets between 1986 and 1989. The findings indicate that banks in Germany, the United Kingdom, France and Spain are monopolistic competitive during the sample period. A similar approach was adopted by Molyneux et al.(1996) for Japan to test for evidence of contestability. The results show that the contestable manner of which incumbent banks act limits the entry of new domestic institutions into commercial banking. Competitive conditions in the Chinese commercial banking industry during a period of major structural change were analyzed by Fu (2009). In particular, Rosse-Panzar H-statistic is estimated for a panel of 76 banks over the period 1997-2006. This results too indicate that Chinese banking system is monopolistic competitive in general.

Panzar-Ross approach has also being used in cross country studies. For example, Staikouras and Koutsomanoli Fillipaki (2006) used this approach for the whole European Union and disclosed that European banks are monopolistic competitive. Claessens and Laeven (2003) use Panzar-Ross H statistics to measure the level of bank competition in their studies which aimed at identifying factors associated with the numerical value of $\mathrm{H}$ for 50 developed and developing countries. They further compare these statistics with the countries' banking system structures and regulatory regimes. However, no evidence was found to prove that the competitiveness negatively relates to banking system concentration. The PR model has been extensively used to analyze the nature of competition in mature banking systems. However, Claessens and Laeven (2003) include Kenya, Nigeria, and South Africa in their cross-country study. Later on, Buchs and Mathisen (2005) apply PR model for Ghana and find evidence for a noncompetitive market structure in the Ghanaian banking system, which may be hampering financial intermediation. Their study further argues that the structure as well as the other market characteristics, constitute an indirect barrier to entry, thereby shielding the large profits in the Ghanaian banking system. Hauner and Peiris (2005) too find that the level of competition has increased significantly in the banking system of Uganda and has been associated with a rise in efficiency. Many subsequent studies (Prasad and Ghosh (2005); Fu (2009) applied this approach in the context of developing countries.

A new approach to measuring competition recently has been introduced by Boone $(2000,2004)$ and has been applied in some recent studies. Leuvensteijn et al, (2007) for the first time applied this method to the banking industry of the five major countries in the Euro area and the UK, the US and Japan, for comparison. Their findings indicate that over the period 1994-2004 the US had the most competitive loan market, whereas overall loan markets in Germany and Spain were among the best competitive in the EU. Leuvensteijn et al, (2008) used this measure and study the effect of loan market competition on the loan and deposit interest rates during 1994-2004. He finds evidence for stronger competition implies significantly lower spreads between bank and market interest rates for most loan market products. However, the Boon indicator is also not free from disadvantages. The major disadvantage of the Boone-indicator as explained by Leuvensteijn et al, (2007) is that it assumes that banks generally pass on at least part of their efficiency gains to their clients.

Thorough analysis of existing empirical findings shows that there is no single measure of competition that has been accepted and applied in all the studies. Some studies have even used two approaches to measure the level of competition and have found contradictory findings. (e.g. Valverde et al, (2009) used both Lerner Index and HHI. This has been perhaps due to the complexity and difficulty in considering banking sectors of different countries uniformly. The banking sectors of a country reflect the characteristics of political, institutional and regulatory background of that country. Hence, the applicability of an approach to measure the degree of bank competition may vary across countries. However, what stems from the analysis of existing literature is that the level of bank competition needs to be measured in a way which considers the actual conduct of banks, as the competition is not merely concentration.

The PR model has been widely applied to analyze the nature of competition in more developed banking systems, however more recently outreached its application in banking systems of under developed economies (E.g.Buchs and Mathisen (2005); Claessens and Leaven (2003). Being 'non-structural' is the fundamental explanation behind utilizing this approach. It has some appealing highlights as well, which justifies its popularity in the empirical banking literature. First it is easy to estimate in a form of regression with only limited number of explanatory variables. Second, the P-R model requires only firm-level data; hence it is robustly extendable to with the size of the market. Thus reviewing all the approaches the present study conceptualize the degree of competitiveness based on 'new empirical industrial organization' (NEIO) literature measures competition without using explicit information about the structure of the market. 


\section{Research and Methodology}

This study employed New Empirical Industrial Organization (NEIO) approach, of which the actual firm performance is considered rather than market structure when assessing the degree of competitiveness. The H-statistic, which is the abbreviated form of Panzar - Rosse (PR) approach was used in this study to measure bank market competition. The H statistic is the sum of elasticities of a firm's revenue in relation to input prices in a reduced form revenue equation.

$$
\log T R_{i t}=\alpha+\beta_{1} \log I P L_{i t}+\beta_{2} \log I P F_{i t}+\beta_{3} \log I P C_{i t}+\lambda_{1} \log T A_{i t}+\lambda_{2} \log N P L_{i t}+e_{i t}
$$

Panzar and Rosse (1977), show that the sum of input price elasticities, $H=\sum_{i=1}^{n} \beta_{i}$ reflects the magnitude of competitiveness of the market. This study estimates the PR model assuming three input factors; labour, funds, and capital and single output (gross interest revenue) production function.

$T R$ is the dependent variable and the proxy for bank's output price. It is measured as the ratio of total revenue to total assets. The IPL is the input price of labour and is proxies through the ratio of personnel expenses to total assets. IPF and IPC represent the input price of funds and input price of capital respectively. Where, IPF measured with ratio of interest expenses made on deposit to total deposits while the ratio of operating and administrative expenses to bank's total assets were used to measure input price of capital. Equation 1 further incorporated with bank size, $T A$ to control for potential effects of size on interest revenue and thus identifying possible scale economies. Incorporating this variable is especially helpful in the Sri Lankan context because only few banks are dominating the commercial banking sector in Sri Lanka. Another control variable is NPL. If the non-performing loans are kept existing and continuously rolled over, the resources are locked up and banks' ability to earn interest would be low. Assuming this effect on interest revenue of the bank, NPL was incorporated in the model as a control variable. The definition of NPL of this study is the ratio of non-performing loans to gross loans of the bank. Subscript $i t$ represents the $i$ th bank in time $t$. All the variables are in $\log$ form, with the coefficients indicating their corresponding elasticities. Table 1 below show the variables, their abbreviations and the measurement of the econometric model of the study (Equation 1)

Table 1: Definition of variables

\begin{tabular}{|c|c|c|}
\hline Variable & Abbreviation & Measurement \\
\hline Total Revenue & TR & Ratio of total revenue to total assets \\
\hline Input Price of labour & IPL & Ratio of personnel expenses to total assets \\
\hline Input Price of Funds & IPF & $\begin{array}{l}\text { Ratio of interest expenses made on deposit to total deposits } \\
\text { Ratio of operating and administrative expenses to bank's total assets }\end{array}$ \\
\hline Input Price of Capital & IPC & $\begin{array}{l}\text { Total Assets of the bank } \\
\text { Ratio of non-performing loans to gross loans of the bank }\end{array}$ \\
\hline Total Assets (Bank size) & TA & \\
\hline Non-performing loans & NPL & \\
\hline
\end{tabular}

Due to the inherent properties of time series i.e., the correlation of a series with its own past and future values of the dependent variable, the Ordinary Least Squires will not be appropriate to estimate the revenue equation. Therefore, the Estimated Generalized Least-Squares (EGLS) procedure were used, as applying it believed to be more efficient with a bigger sample. In this EGLS procedure, the Period Seemingly Unrelated Regression (SUR) weights were used to correct for period heteroskedasticity as well as general correlation of observations within the cross-section. The sample covers the whole commercial banking sector for the period 1996 to 2018 .

\section{Results and Discussion}

\section{Descriptive Statistics}

Before estimating bank competition, some descriptive statistics in relation to dependent and independent variables have been computed in order to get a preliminary understanding about the behaviour of the variables in the Sri Lankan context. Table 2 shows the summary statistics for the variables of the competition measure. 
Table 2: Summary Statistics of Sri Lankan banking sector operations 1996-2018

\begin{tabular}{llllll}
\hline Variable & Mean & Median & Maximum & Minimum & Std. Dev. \\
\hline Total revenue (Rs. Millions) & 9605 & 1628 & 58860 & 12 & 11177 \\
\hline Input price of funds (Rs. Millions) & 3832 & 714 & 41711 & 3 & 6908 \\
\hline Input price of labour (Rs. Millions) & 1180 & 205 & 12567 & 7 & 2231 \\
\hline Input price of capital (Rs. Millions) & 1023 & 299 & 7550 & 0 & 1491 \\
\hline Total Assets (Rs. Millions) & 64669 & 18777 & 730065 & 150 & 107143 \\
\hline Total Deposits (Rs. Millions) & 45431 & 11085 & 523319 & 85 & 79215 \\
\hline Return on assets \% & 1.23 & 1.31 & 11.5 & -27.1 & 2.94 \\
\hline Non-performing loans \% & 4.06 & 0.19 & 38 & 0 & 7.16 \\
\hline Number of branches & 81 & 12 & 716 & 1 & 131 \\
\hline
\end{tabular}

Note: Based on stacked data from 1996-2018.

Source: Calculations by the author

The mean nonperforming loan ratio of the sample over the period under investigation is around $4 \%$, indicating a low risk of Sri Lankan banking sector. However, Interest revenue, interest expenses, personnel and operating expenses depict a greater level of deviation across individual banks, indicating the diversity of banks in size and in operations. These variations had to be carefully considered in selecting the suitable estimation method.

The result of the regression model is depicted in the table 3 below. The adjusted $R$-squared of the model, which measure the goodness of fit, is reported as 0.72 . This is considered as satisfactory. According to the results of the regression, both input price elasticity of labour (IPL) and funds (IPF) were highly positive and statistically significant in explaining the elasticity of bank revenue. However, price elasticity of capital (IPC) and size (TA) were not very strong but statistically significant, whereas non-performing loans (NPL) was insignificant in explaining bank revenue elasticity. Therefore, when estimating the H statistics model for Sri Lankan banking sector, the study applied the general-to-specific approach in which the modeler simplifies the initially general model that adequately characterizes the empirical evidence within the theoretical framework. Accordingly, the regression started with the broad set of explanatory variables as stated in the Equation 1 and subsequently, eliminate one at a time, the variable with the least significant coefficient, stopping at the $10 \%$ level of significance. Following this methodology, the researcher eliminated ratio of non-performing loans (NPL) as non-significant variable. As a result, the explanatory power of input price of labour and funds improved a little.

\section{Measuring competition}

The regression results with most significant variables are shown below. Hence a new reduced form equation is derived as Equation 1(a) with most significant variables which were included in Equation 1.

Table 3: Regression Results-Equation 2(a)

\begin{tabular}{lll}
\hline Variable & Coefficient \\
\hline Constant C & $-0.342 * * * \quad(-5.56)$ \\
Input Price of Labor IPL & $0.24 * * * \quad(10.76)$ \\
Input Price of Labor IPL & $0.33 * * * \quad(20.09)$ \\
Input Price of Labor IPL & $0.007 * * \quad(1.78)$ \\
Size TA & $0.02 * * * \quad(2.19)$ \\
\hline with adjusted $\mathbf{R}^{\mathbf{2}}$ & 0.72 \\
F-statistics & $202.63 * * *$ \\
Durbin-Watson stat & 1.97 \\
\hline
\end{tabular}

$$
\begin{aligned}
& H=\sum_{i=1}^{n} \beta_{i} \\
& \boldsymbol{H}=\boldsymbol{\beta}_{\mathbf{1}}+\boldsymbol{\beta}_{2}+\boldsymbol{\beta}_{3} \\
& \boldsymbol{H}=\mathbf{0 . 2 4}+\mathbf{0 . 3 3 + 0 . 0 0 7} \\
& \boldsymbol{H}=\mathbf{0 . 5 8}
\end{aligned}
$$

Notes : $\mathrm{t}$ values for coefficient are in parentheses. $* p<0.1, * * p<0.05, * * * p<0.001$,

As the results of the estimated reduced form revenue equation shows above, the estimated $H$ statistic is 0.58 for the sample period. This value does not lend support for a perfectly competitive banking market in Sri Lanka, as the estimated $H$ statistic significantly differs from 1 . This value is also significantly non-negative (closer to zero), thus offers no evidence for a monopoly in the banking 
market. The results suggest that for the observed period, the Sri Lankan banking sector is characterized by monopolistic competition according to the PR classification. This indicates that an increase in input prices will lead to a less than proportional increase in revenues, as the demand for banking faced by individual bank is inelastic. As this value is in the range between 0.5 and 1 , the estimated $H$ statistic supports evidence for a moderately competitive market in the Sri Lankan banking industry. This result is quite similar to the $H$ statistic estimated by Bikker et al (2006a). This study analyzed H statistics for 101 countries including Sri Lanka over 1996-2004, based on 25,000 banks. The assessed $H$ statistic for Sri Lanka was described as 0.69 for the period 1994-2001, which is quite similar to the $\mathrm{H}$ statistics estimated for the similar period of the current study.

An analysis of the sign and significance of the regression coefficients (Equation 1a) indicates that the price of labour and price of funds are positive and statistically significant at 1\% level for the observed period. The results indicate that, for the period 1996-2018, the price of funds provides the highest contribution to the explanation of banks' revenues (and therefore to the $H$ statistic), followed by the price of labour. The cost of capital effect of bank revenue is marginal compared to the other input prices. The differences in the magnitude of impact of capital prices (operating expenses) on interest revenue among banks might be the reason for less explanatory power of cost of capital in the estimated model. However, these results are consistent with previous studies. This is because, for most of the countries, price of labour and price of funds are most powerful variables affecting bank revenue (see Bikker et al 2006, Prasad and Ghosh, 2005), but not the capital prices. None of the bank specific control variables included in the model was strong enough in explaining banks' revenue and thus contributing to $H$ statistics. Accordingly, the size of the bank is not a powerful factor explaining the revenue of the Sri Lankan banking sector, hinting no beneficial effects of diversification. Similarly, the credit risk supports no evidence in affecting interest revenue of banks.

\section{Competitive conditions among different ownership forms}

The most common criticism for developing countries on bank competition is the anticompetitive behavior or the monopoly power of state-owned banks. Hence, an analysis was carried out to explore the differences if exist among the competitive behavior of banks with their ownership category. Therefore, the Equation 1 was re-estimated for subsets domestic private banks, state banks and foreign banks. As per the results of the regression analysis the $\mathrm{H}$ statistics for domestic banks and state banks were at 0.58 and 0.57 respectively. However, the $\mathrm{H}$ statistics for foreign banks was at 0.31 . The time series behavior of these three subsets is shown in figure 1 .

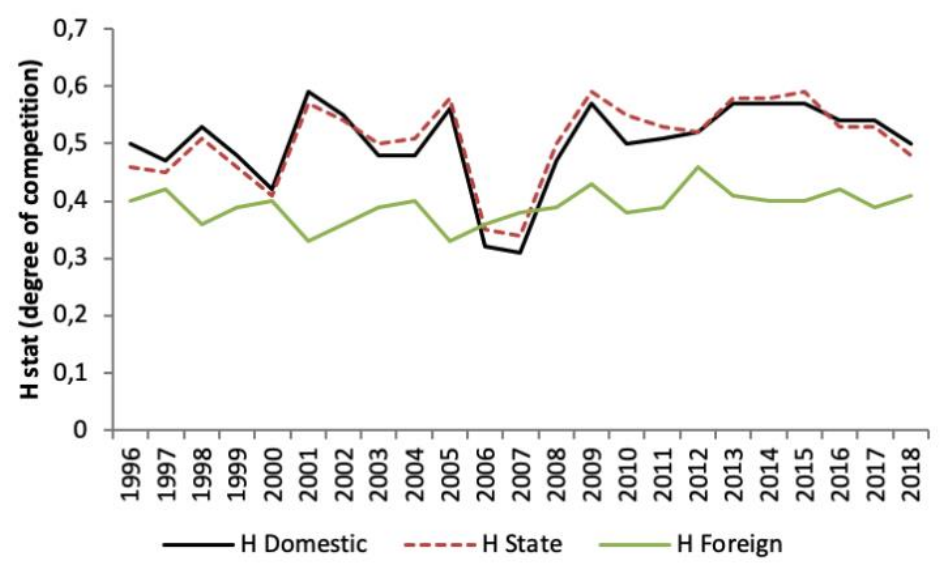

Figure 1: Time series behavior of bank competitiveness

Few important observations can be highlighted in the time series patterns of bank competition. First, competitiveness of state banks and domestic private banks reveal no significant difference in their level of competitiveness as well as its time dynamics. This result questions the validity of common wisdom that state banks are less competitive. When private sector new dynamic banks enter to the market, a renaissance of state banks had been noticeable during this period. State banks had to compete in the market to retain their market share which they had been losing due to competition of other domestic and foreign banks operated in the country. The striking observation is lower level of competition among foreign banks. The foreign banks operated in Sri Lanka generally serving to a niche market. Therefore, their competitive behavior in the market is not very observable. The reason for this according to Zaheer and Mosakowski (1997) is the liability of foreignness, that initially leaves them intrinsically weaker than their domestic competitors. However, after 2004 a slight increasing pattern in foreign bank competition can ben observed. This is because the foreign banks too stepped to a competitive edge with more localized banking service. This is quite evident with the strategic behavior of the two largest foreign banks operated in the country, i.e. HSBC and Standard Chartered Bank.

\section{Conclusions}

The paper aimed at testing the competitive behavior of Sri Lankan banking sector during the period 1996-2018. The moderate level of $\mathrm{H}$ statistic found in the present study indicates a moderate competitiveness among the commercial banks in the Sri Lankan banking sector. The findings reveal no significant difference between state-owned and private banks in their level of competitiveness, however 
a significant difference between local and foreign banks. The Sri Lankan banking industry is severely concentrated in one main province (Western Province) where the capital city is located. Specially most of the foreign bank branches are operated only in Colombo and suburbs. Moreover, Sri Lankan bank customer base is small. Thus, all banks are competing to capture the same customers resulting in having to slash down the rate of interest in to retain them. On the other hand, the high cost incurred in managing the portfolios, human capital and overheads have become challenges to the banking sector in recent Sri Lanka. Thus, the operating environment of all banks including state banks, need to change significantly making the banking industry more competitive.

The findings of this study offer some important practical implications. First, it highlights the importance of non-price competition in the banking sectors of developing countries. Competition (bank) is sometimes assumed to focus only on price (interest rate). However, banks, in addition to being the suppliers of financial services, can also compete in other ways, for example by developing the quality of existing financial products and services, by using their interpersonal skills, or investing in research to develop new financial products. As in most instances the interest rate depends on government policies, competition in Sri Lankan banking sector is more on non-price. That means, to be sustainable in the future, banks must constantly respond to changing customer demand through various products, services and innovations to attract customers. The effort of all banks towards re-working and aligning their strategy to attract and retain their customer base would be the major challenges to achieve higher level competition in the banking industry in future. The second important implication of the present study is that it gives some useful insight into the nature and trends of banking sector competitiveness of underdeveloped countries. The Sri Lankan banking sector is highly concentrated around two state owned banks. However, the findings of the study reveal that the degree of competitiveness among state banks is also par with that of private banks. These findings substantiate the argument that the degree of concentration in a specific banking market is not a reliable proxy for the intensity of competition.

\section{References}

Bikker, J. A., Spierdijk, L., \& Finnie, P. (2006). Misspecification of the Panzar-Rosse Model: Assessing competition in the banking industry. DNB Working Papers 114, Netherlands Central Bank, Research Department: http://notices-pdf. com/panzar-pdf. html.

Boone, J. (2000) Competition. Discussion Paper Series No. 2636, Centre for Economic Policy Research, United Kingdom.

Boone, J. (2004) A New Way to Measure Competition. Discussion Paper Series No. 4330 Centre for Economic Policy Research, United Kingdom. https://doi.org/10.1111/j.1468-0297.2008.02168.x

Bresnahan, T. F. (1982). The oligopoly solution concept is identified. Economics Letters, 10(1-2), 87-92. https://doi.org/10.1016/0165-1765(82)90121-5

Buchs, T. D., \& Mathisen, J. (2005). Competition and efficiency in banking: Behavioral evidence from Ghana. http://dx.doi.org/10.5089/9781451860368.001

Carbo-Valverde, S., Rodriguez-Fernandez, F., \& Udell, G. F. (2009). Bank market power and SME financing constraints. Review of Finance, 13(2), 309-340. https://doi.org/10.1093/rof/rfp003

Claessens, S., \& Laeven, L. (2003). Financial development, property rights, and growth. the Journal of Finance, 58(6), 24012436. https://doi.org/10.1046/j.1540-6261.2003.00610.x

Fry, M. J. (1995). Financial development in Asia: some analytical issues. Asian-Pacific Economic Literature, 9(1), 40-57. https://doi.org/10.1111/j.1467-8411.1995.tb00103.x

Fu, X. M., \& Heffernan, S. (2009). The effects of reform on China's bank structure and performance. Journal of Banking \& Finance, 33(1), 39-52. https://doi.org/10.1016/j.jbankfin.2006.11.023

Guzman, M. G. (2000). Bank structure, capital accumulation and growth: a simple macroeconomic model. Economic Theory, 16(2), 421-455. https://doi.org/10.1007/PL00004091

Hainz, C., Weill, L., \& Godlewski, C. J. (2013). Bank competition and collateral: Theory and evidence. Journal of Financial Services Research, 44(2), 131-148. https://doi.org/10.1007/s10693-012-0141-3

Hauner, D., \& Peiris, S. (2005). Bank efficiency and competition in low-income countries: The case of Uganda. IMF Working Paper No. 05/240 https://doi.org/10.1080/00036840600972456

Klein, M. A. (1971), A theory of the banking firm. Journal of Money, Credit, and Banking, 3, pp. $205-218$. https://doi.org/10.2307/1991279

Lau, L. J. (1982). On identifying the degree of competitiveness from industry price and output data. Economics Letters, 10(1-2), 9399. https://doi.org/10.1016/0165-1765(82)90122-7

Maudos, J., \& De Guevara, J. F. (2004). Factors explaining the interest margin in the banking sectors of the European Union. Journal of Banking \& Finance, 28(9), 2259-2281. https://doi.org/10.1016/j.jbankfin.2003.09.004

McKinnon, R. (1973). Money and capital in economic development, the Brookings institute. Washington, DC. https://doi.org/10.2307/1992568

Molyneux, P., Lloyd-Williams, D. M., \& Thornton, J. (1994). Competitive conditions in European banking. Journal of banking \& finance, 18(3), 445-459. https://doi.org/10.1016/0378-4266(94)90003-5

Molyneux, P., Thornton, J., \& Llyod-Williams, D. M. (1996). Competition and market contestability in Japanese commercial banking. Journal of Economics and Business, 48(1), 33-45. https://doi.org/10.1016/0148-6195(95)00047-X 
Nathan, A., \& Neave, E. H. (1989). Competition and contestability in Canada's financial system: Empirical results. Canadian Journal of economics, 35(4) 576-594. https://doi.org/10.2307/135541

Panzar, J. C., \& Rosse, J. N. (1987). Testing for "monopoly" equilibrium. The journal of industrial economics, $443-456$. https://doi.org/10.2307/2098582

Prasad, A., \& Ghosh, S. (2005). Competition in Indian banking. South AsiaEconomic Journal, 8(2), 265-284 https://doi.org/10.1080/13571516.2019.1592995

Shaffer, S. (1989). Competition in the US banking industry. Economics letters, 29(4), 321-323. https://doi.org/10.1016/01651765(89)90210-3

Shaffer, S. (1993). A test of competition in Canadian banking. Journal of Money, Credit and Banking, 25(1), 49-61. https://doi.org/10.2307/2077819

Shaw, E. S. (1973). Financial deepening in economic development. The Journal of Finance, 29(4) 1345-1348 https://doi.org/10.2307/2978421

Staikouras, C. K., \& Koutsomanoli-Fillipaki, A. (2006). Competition and concentration in the new European banking landscape. European Financial Management, 12(3), 443-482.

https://doi.org/10.1111/j.1354-7798.2006.00327.x

Van Leuvensteijn, M., Bikker, J. A., van Rixtel, A. A., \& Kok, C. (2007). A new approach to measuring competition in the loan markets of the euro area. Applied Economics, 43(23), 3155-3167 DOI: 10.1080/00036840903493234

Van Leuvensteijn, M., Kok, C., Bikker, J. A., \& Van Rixtel, A. A. (2008). Impact of bank competition on the interest rate passthrough in the euro area. Working paper series 885, European Central Bank https://doi.org/10.1080/00036846.2011.617697

Zaheer, S., \& Mosakowski, E. (1997). The dynamics of the liability of foreignness: A global study of survival in financial services. Strategic management journal, 18(6), 439-463. https://doi.org/10.1002/(SICI)1097-0266(199706)18:6<439::AIDSMJ884>3.0.CO;2-Y

Publisher's Note: SSBFNET stays neutral with regard to jurisdictional claims in published maps and institutional affiliations.

\section{(ब) (1)}

(C) 2021 by the authors. Licensee SSBFNET, Istanbul, Turkey. This article is an open access article distributed under the terms and conditions of the Creative Commons Attribution (CC BY) license (http://creativecommons.org/licenses/by/4.0/).

International Journal of Research in Business and Social Science (2147-4478) by SSBFNET is licensed under a Creative Commons Attribution 4.0 International License. 